Л. А. Коранг, Л. В. Деримедвідь

\title{
Антиексудативні властивості рідкого спиртово- водного екстракту листя аїру звичайного (Acorus calamus L.)
}

Національний фармацевтичний університет, м. Харків

Ключові слова: Acorus calamus L., карагеніновий набряк, гістаміновий набряк, рідкий спиртово-водний екстракт листя аїру звичайного, антиексудативна активність

Запалення є частиною складної біологічної відповіді та захисною пристосувальною реакцією організму на дію різних пошкоджуючих факторів: біологічних, фізичних, хімічних як екзогенного, так і ендогенного походження $[1,2]$. Навколо вивчення новітніх патогенетичних ланок запального процесу та шляхів його корекції сфокусовані дослідження світової наукової спільноти [2].

Лікарськими засобами першої лінії для фармакологічної корекції запальних процесів $€$ нестероїдні протизапальні засоби (НПЗ3), але коротко та/ або довгострокові системні побічні ефекти цієї групи препаратів [2, 3] обмежують їхнє застосування в ряді випадків [4].

Світові та українські тенденції медицини сьогодення свідчать про стрімке зростання інтересу до фітотерапії $[5,6]$. Достойною альтернативою фармакотерапії НПЗЗ або суттєвим доповненням до неї може бути застосування препаратів рослинного походження, які здатні впливати на різні ланки запального процесу. Перспективною лікарською рослиною сировиною 3 прогнозованими протизапальними властивостями є листя аїру звичайного (Acorus calamus L.) [7, 8].

Рідкий спиртово-водний екстракт листя аїру звичайного (Acorus calamus L.) (РСВЕЛА) був отриманий на кафедрі ботаніки НФаУ аспірантом М. С. Яременком під керівництвом професора Т. М. Гонтової.

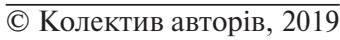

Мета дослідження - вивчення антиексудативних властивостей РСВЕЛА за експериментальних набряків у щурів.

Матеріали та методи. Антиексудативні властивості РСВЕЛА досліджено на білих безпородних щурах на моделі карагенінового та гістамінового набряків [9].

Дослідження проводили в ЦНДЛ НФаУ, що сертифікована ДЕЦ МОЗУ (посвідчення від 08.12.2015 № 058/15, чинне до 07.12.2019). Під час експерименту тварини знаходилися у віварії ЦНДЛ НФаУ за температури повітря 20-22 ${ }^{\circ} \mathrm{C}$, природного світлового режиму «день-ніч», у стандартних клітках, на стандартному харчовому раціоні. Усі маніпуляції з тваринами проводилися відповідно до вимог GLP, рекомендацій ДЕЦ МОЗУ [9], «Загальних етичних принципів експериментів на тваринах (Україна, 2001 р.), Закону України від 21 лютого 2006 року № 3447-IV зі змінами «Про захист тварин від жорсткого поводження", ухвали I Національного конгресу 3 біоетики (Київ, 2007 р.) та Європейської ковенції про захист хребетних тварин, які використовуються 3 експериментальною або іншою науковою метою [10].

Карагеніновий набряк відтворювали шляхом субплантарного введенням 0,1 мл 1 \% карагеніну ( Fluka», Швейцарія) у праву задню лапу щурів [9]. Набряк сприймався як ознака запалення, за розвитком якого спостерігали в динаміці через $30,60,90,120,180$ i 240 хв, а також через 24 год, для чого вимірювали об'єм лап (у см${ }^{3}$ ) за допомогою цифрового плетизмометра Panlab (Іспанія) моделі LE 7500 версії $\mathrm{V} 29 / 10 / 2014$.

За проведення дослідів зі встановлення антиексудативних властивостей 
РСВЕЛА на моделі карагенівого набряку всі тварини були розділені на 6 груп по 6 щурів: I - контрольна патологія (тварини, яким вводили субплантарно розчин карагеніну та внутрішньошлунково вводили 0,5 мл/кг дистильованої води); II - тварини, яким субплантарно вводили розчин карагеніну та внутрішньошлунково вводили досліджуваний РСВЕЛА у дозі 0,5 мл/кг (ефективна доза, встановлена в попередніх дослідженнях); щурам III та IV групи на тлі введення карагеніну внутрішньошлунково вводили препарати порівняння: диклофенак натрію в дозі 8 мг/кг (капс. по 25 мг виробництва ТОВ «Харківське фармацевтичне підприємство «Здоров'я народу», Україна) [9] і кверцетин у дозі 11 мг/кг (гран. по 2 г виробництва НВЦ «БХФЗ», Україна) [9]. VI групу склали інтактні тварини, яким вводили субплантарно 0,1 мл фізіологічного розчину.

Досліджуваний екстракт і препарати порівняння застосовували в лікувальнопрофілактичному режимі: внутрішньошлунково одноразово щоденно протягом 5 діб до моделювання запалення, останній раз за 1 год до ін'єкції карагеніну. РСВЕЛА в досліджуваній дозі 0,5 мл/кг для зручності дозування попередньо розводили водою та вводили з розрахунку 0,5 мл на 100 г маси тварини.

Антиексудативні властивості РСВЕЛА також вивчали за умов гістамінового («Sigma-Aldrich», США) запалення лапи в щурів [9]. Як відомо, гістамін $€$ не тільки медіатором алергії, але й бере участь у розвитку запальних реакцій [9]. Тварини були розподілені на групи по 6 щурів у кожній: I - контрольна патологія (тварини, яким субплантарно вводили $0,1 \%$ розчин гістаміну в об'ємі 0,1 мл і внутрішньошлунково вводили 0,5 мл/кг дистильованої води); II щури з гістаміновим набряком, яким вводили досліджуваний РСВЕЛА в дозі 0,5 мл/кг; III, IV і V групи - тварини 3 гістаміновим набряком, які отримували препарати порівняння: диклофенак натрію, кверцетин у дозах, вказаних вище, та блокатор гістамінових $\mathrm{H}_{1}$-рецепторів - лоратадин у дозі $1 \mathrm{мг} /$ кг (таб. Лоратадин-Дарниця по 10 мг виробництва ПАТ ФФ «Дарниця») від- повідно [9]. VI групу склали інтактні тварини, яким вводили субплантарно 0,1 мл фізіологічного розчину.

Досліджуваний екстракт і препарати порівняння вводили внутрішньошлунково 1 раз на добу протягом 5 діб і на 6 добу за 1 год до ін'єкції $0,1 \%$ розчину гістаміну.

Вибір лікувально-профілактичного режиму використання досліджуваного препарату ми обрали у зв'язку з тим, що базовими препаратами для лікування запальних процесів є НПЗ3, а засоби рослинного походження, у тому числі й РСВЕЛА, на наш погляд, мають допоміжний характер.

За розвитком набряку спостерігали в динаміці через 30,60 і 90 хв, для чого вимірювали об'ем лап (у см${ }^{3}$ ) за допомогою цифрового плетизмометра Panlab (Іспанія) моделі LE 7500 версії $\mathrm{V} 29 / 10 / 2014$.

Антиексудативний ефект досліджуваного екстракту та препаратів порівняння за умов карагенінового та гістамінового набряків розраховували за формулою [9]:

$$
\mathrm{AA}=\left(\mathrm{V}_{\text {кп }}-\mathrm{V}_{\text {д }}\right) / \mathrm{V}_{\text {кп }} \cdot 100,(\%)
$$

де, AA - антиексудативна активність, \% ;

$\mathrm{V}_{\text {кп }}\left(\mathrm{cm}^{3}\right)$ - медіана об'єму стопи в тварин з групи контрольної патології;

$\mathrm{V}_{\text {д }}\left(\mathrm{cm}^{3}\right)$ - медіана об'єму стопи в групі тварин, які отримували досліджувані засоби.

Через 24 год після введення карагеніну та гістаміну в тварин проводили клінічне дослідження крові та визначали кількість лейкоцитів уніфікованими методом підрахунку в камері Горяєва та рівень ШОЕ за допомогою стандартних методів $[9,11]$.

Отриманий масив даних обробляли методами варіаційної статистики (медіана, верхній і нижній квартилі) з використанням непараметричних методів аналізу (критерій Крускала-Уолліса, Манна-Вітні). Прийнятий рівень значущості $\mathrm{p}<0,05$. Для отримання статистичних висновків використовували стандартний пакет програм Statistica (версія 6) [12].

Результати та їх обговорення. У результаті проведених дослідів було 
встановлено, що РСВЕЛА чинить антиексудативну дію. Антиексудативна активність РСВЕЛА за карагенін-індукованого набряку на максимумі запалення становила 68,9 \% $(\mathrm{p}<0,05)$ на 120 хв та $79,5 \%(\mathrm{p}<0,05)$ на 180 хв (табл. 1).

На наш погляд, пригнічення розвитку набряку під впливом РСВЕЛА на 120 хв (2 год) карагенін-індукованого запалення ймовірно зумовлене інгібуванням медіаторів ранньої фази запального процесу, таких як гістамін, 5-гідрокситриптамін і брадикінін, тоді як антиескудативна дія екстракту на 180 хв (3 год), вочевидь, пов'язана 3 пригніченням під його впливом синтезу простагландинів [1, 7].

За ступенем пригнічення ексудативних процесів протягом усього періоду дослідження РСВЕЛА (10,0-79,5 \%) дещо поступається диклофенаку натрію $(28,7-80,1 \%)$ і перевищує дію препарату порівняння кверцетину $(4,6-80,1 \%)$. Вибір диклофенаку натрію як препарату порівняння був обумовлений тим, що він є класичним протизапальним засобом неселективного впливу, основним механізмом дії якого є гальмування біосинтезу простагландинів шляхом пригнічення циклооксигенази (ЦОГ) [2, 3]. Домінуючим механізмом протизапальної активності кверцетину (флавоноїд флавонового класу) є інгібування 5-ліпооксигенази (антилейкотрієнова дія). Окрім цього, встановлено, що кверцетин чинить пряму пригнічуючу дію на секрецію гістаміну, функціональну активність алоантигенспецифічних цитотоксичних Т-лімфоцитів, інтерлейкіну 8 (ІЛ-8), фактора некрозу пухлин $\alpha(\Phi Н П-\alpha)[5,13]$.

Одним з показників, що характеризують інтенсивність запального процесу, є зміни клінічного аналізу крові.

Встановлено, що за карагенінового набряку спостерігається збільшення рівня лейкоцитів у 1,7 разу та збільшення рівня ШОЕ в 1,5 разу $(\mathrm{p} \leq 0,01)$ порівняно 3 інтактними тваринами (рис. 1). На фоні використання РСВЕЛА рівень лейкоцитів зменшився в 1,3 разу $(\mathrm{p} \leq 0,01)$ порівняно 3 нелікованими тваринами, а показник ШОЕ зменшився

\begin{tabular}{|c|c|c|c|c|c|}
\hline & 女ా & 1 & $\begin{array}{l}0 \\
0 \\
0\end{array}$ & F & $\begin{array}{l}n \\
\text { Ñ } \\
\text { in }\end{array}$ \\
\hline & 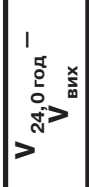 & 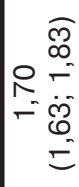 & 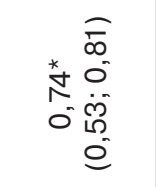 & 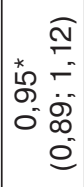 & 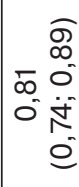 \\
\hline$\frac{5}{8}$ & ஓ & 1 & $\begin{array}{l}0 \\
0^{-}\end{array}$ & 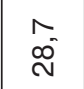 & $\stackrel{0}{\nabla}$ \\
\hline 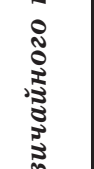 & 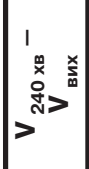 & 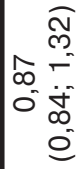 & 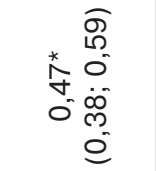 & 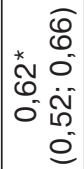 & $\begin{array}{r}\widehat{\hat{O}} \\
m \\
\infty \\
\infty \\
0 \\
0 \\
0 \\
0 \\
0 \\
0\end{array}$ \\
\hline$: \frac{\pi}{8}$ & \& & 1 & $\begin{array}{l}\text { م) } \\
\text { م }\end{array}$ & - & '. \\
\hline 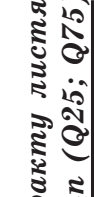 & $>^{1}$ & 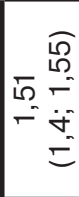 & 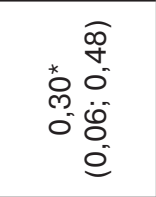 & 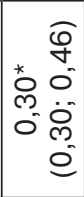 & 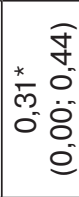 \\
\hline 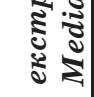 & \&̊ & 1 & $\begin{array}{l}\infty \\
\infty \\
0\end{array}$ & $\begin{array}{l}\infty \\
\infty \\
\infty\end{array}$ & $\begin{array}{l}\text { क } \\
\infty \\
0\end{array}$ \\
\hline 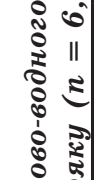 & 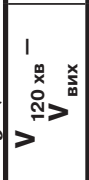 & 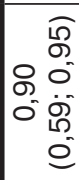 & 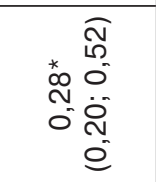 & 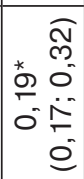 & 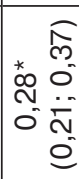 \\
\hline 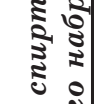 & $\frac{2}{4}$ & 1 & $\begin{array}{l}\stackrel{m}{m} \\
\underline{m}\end{array}$ & $\bar{m}$ & $\begin{array}{l}\nabla^{-} \\
\dot{\sigma}\end{array}$ \\
\hline 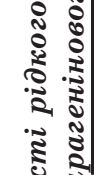 & 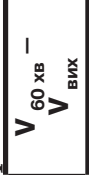 & 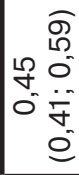 & 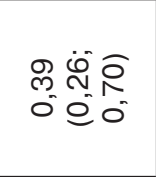 & 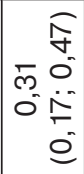 & 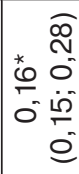 \\
\hline $\begin{array}{l}0 \\
\text { है } \\
0 \\
0\end{array}$ & $\begin{array}{l}0 \\
8\end{array}$ & 1 & $\begin{array}{l}0 \\
\text { O }\end{array}$ & $\begin{array}{l}m \\
\stackrel{+}{q}\end{array}$ & $\stackrel{n}{n}$ \\
\hline 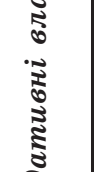 & 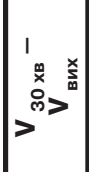 & 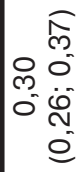 & 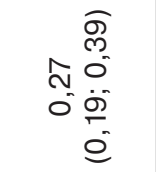 & 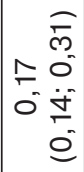 & 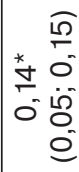 \\
\hline 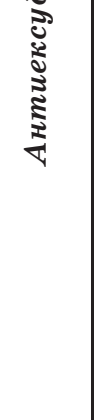 & 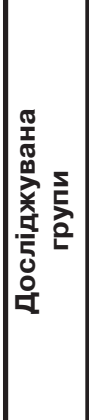 & 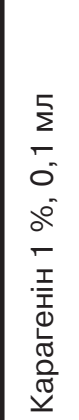 & 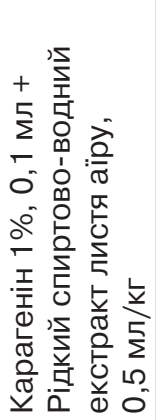 & 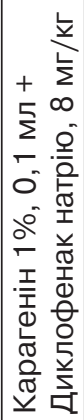 & 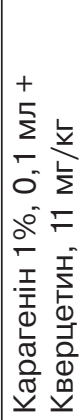 \\
\hline
\end{tabular}


в 1,35 разу. На фоні використання диклофенаку натрію рівень лейкоцитів зменшився в 1,4 разу, а показник ШОЕ зменшився в 1,5 разу порівняно з нелікованими тваринами (p $\leq 0,01)$, а в разі використання кверцетину рівень лейкоцитів зменшився в 1,2 разу ( $\mathrm{p} \leq$ $0,05)$, показник ШОЕ - у 1,2 разу.

Такі зміни свідчать про вірогідне зниження інтенсивності запального процесу за умов застосування РСВЕЛА та диклофенаку натрію та наявність протизапальної дії в кверцетину.

Наступним етапом експерименту стало дослідження ефективності РСВЕЛА за умов гістамінового набряку.

Експериментально встановлено, що за умов гістамінового набряку спостерігається інтенсивне збільшення об'єму лап піддослідних тварин (табл. 2).

РСВЕЛА за умов цієї моделі проявляє антиексудативну дію на рівні 50,8; 27,7 і 50,0 \% відповідно на 30,60 і 90 хв набряку (табл. 2). За виразністю антиексудативної активності РСВЕЛА не поступається всім трьом препаратам порівняння: диклофенаку натрію, кверцетину та лоратадину, що вочевидь вказує на здатність досліджуваного екстракту чинити гальмівний вплив на медіатори ранньої фази запального процесу, в основному біогенні аміни (гістамін).
Дослідження рівня лейкоцитів i ШОЕ в тварин з гістаміновим набряком показало, що в нелікованих тварин спостерігається збільшення рівня лейкоцитів у 1,58 разу та збільшення ШОЕ в 1,48 разу $(\mathrm{p} \leq 0,01)$ порівняно 3 інтактними тваринами (рис. 2). На фоні використання РСВЕЛА рівень лейкоцитів і показник ШОЕ зменшився в 1,2 разу $(\mathrm{p} \leq 0,01)$ порівняно 3 нелікованими тваринами.

На тлі використання диклофенаку натрію рівень лейкоцитів зменшився в 1,3 разу, а показник ШОЕ зменшився в 1,36 разу порівняно з нелікованими тваринами ( $\leq 0,01)$, а при використанні лоратадину спостерігалась лише тенденція до зменшення рівня лейкоцитів i ШОЕ (рис. 2). Ці результати співвідносяться з результатами інших дослідників щодо тенденції до зменшення лейкоцитозу в разі використання диклофенаку натрію за карагенінового запалення [14].

Таким чином, результати проведених досліджень свідчать, що РСВЕЛА (Acorus calamus L.) виявляє антиексудативну дію з полівалентним механізмом реалізації. Ймовірно це зумовлено гальмівним впливом на медіатори ранньої фази запального процесу, ПГ, стабілізацією клітинних і субклітинних мембран і опосередкованим чи прямим пригніченням ЦОГ.

Таблиця 2

Антиексудативні властивості рідкого спиртово-водного екстракту листя аїру на моделі гістамінового набряку $(n=6$, Median (Q25; Q75)

\begin{tabular}{|c|c|c|c|c|c|c|}
\hline Досліджувана група & $\mathbf{V}_{30 \times \text { хв }}-$ & $\begin{array}{c}\mathbf{A A}, \\
\%\end{array}$ & $\mathbf{V}_{60 \text { хв }}-$ & $\begin{array}{c}\text { AA, } \\
\%\end{array}$ & $\mathbf{V}_{90 \text { хв }}-$ & $\begin{array}{c}\text { AA, } \\
\%\end{array}$ \\
\hline Гістамін 0,1%, 0,1 мл & $\begin{array}{c}1,20 \\
(1,13 \\
1,27)\end{array}$ & - & $\begin{array}{c}0,65 \\
(0,49 \\
0,77)\end{array}$ & - & $\begin{array}{c}0,48 \\
(0,26 \\
0,51)\end{array}$ & - \\
\hline $\begin{array}{l}\text { Гістамін 0,1 \%, 0,1 мл + Рідкий } \\
\text { спиртово-водний екстракт } \\
\text { листя аїру, 0,5 мл/кг }\end{array}$ & $\begin{array}{l}0,59^{*} \\
(0,47 \\
0,72)\end{array}$ & 50,8 & $\begin{array}{l}0,47^{\star} \\
(0,30 \\
0,49)\end{array}$ & 27,7 & $\begin{array}{l}0,24^{*} \\
(0,20 \\
0,32)\end{array}$ & 50,0 \\
\hline $\begin{array}{l}\text { Гістамін 0,1\%, 0,1 мл + } \\
\text { Диклофенак натрію, } 8 \text { мг/кг }\end{array}$ & $\begin{array}{l}0,72^{*} \\
(0,31 \\
0,71)\end{array}$ & 40,0 & $\begin{array}{l}0,44^{\star} \\
(0,33 \\
0,57)\end{array}$ & 32,3 & $\begin{array}{r}0,37 \\
(0,33 \\
0,42)\end{array}$ & 22,9 \\
\hline $\begin{array}{l}\text { Гістамін 0,1 \%, 0,1 мл + Лора- } \\
\text { тадин, } 1 \text { мг/кг }\end{array}$ & $\begin{array}{c}0,38^{\star} \\
(0,24 \\
0,51)\end{array}$ & 68,3 & $\begin{array}{c}0,30^{\star} \\
(0,24 \\
0,31)\end{array}$ & 58,3 & $\begin{array}{c}0,13^{\star} \\
(0,03 \\
0,20)\end{array}$ & 72,9 \\
\hline $\begin{array}{l}\text { Гістамін 0,1\%, 0,1 мл + Квер- } \\
\text { цетин, } 11 \text { мг/кг }\end{array}$ & $\begin{array}{l}0,34^{*} \\
(0,27 \\
0,49)\end{array}$ & 71,7 & $\begin{array}{l}0,35^{\star} \\
(0,12 \\
0,48)\end{array}$ & 46,1 & $\begin{array}{l}0,17^{\star} \\
(0,11 \\
0,23)\end{array}$ & 64,6 \\
\hline
\end{tabular}

Примітка. *Достовірно порівняно з групою контрольної патології. 

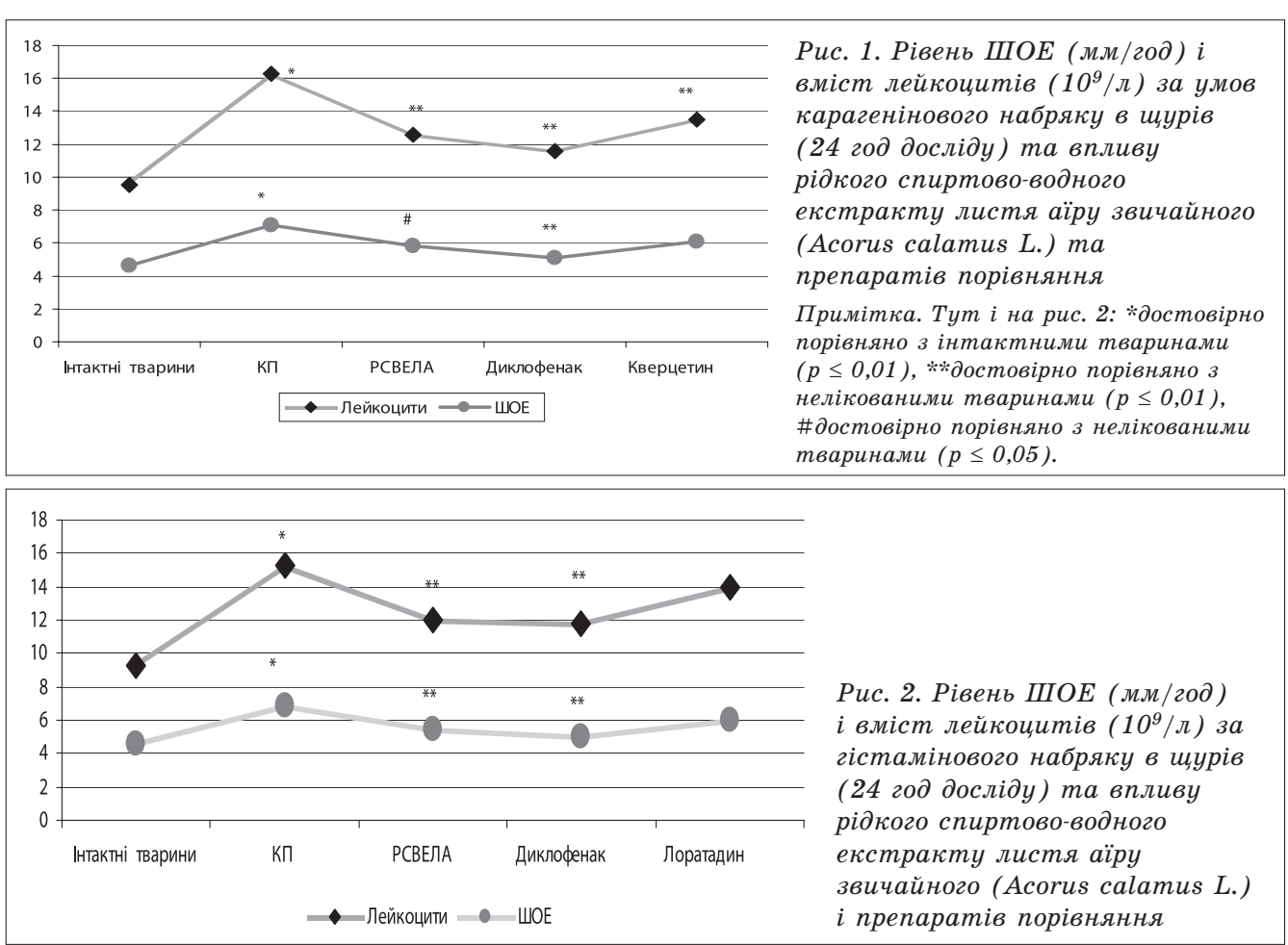

\section{Висновки}

Встановлено, що РСВЕЛА (Acorus calamus L.) виявляє антиексудативну дію. Цей ефект спостерігається як за карагенінового, так і гістамінового набряків, що ймовірно свідчить про полівалентний механізм дії.

Враховуючи те, що спиртово-водний екстракт листя аїру звичайного не поступається, а в деяких випадках перевищує антиексудативну активність препаратів порівняння, отримані дані є основою для подальших доклінічних досліджень з метою створення на його основі нових ефективних фітозасобів для профілактики та фармакокорекції запальних процесів.

1. Inflammatory cytokines mediate the effects of diet and exercise on pain and function in knee osteoarthritis independent of BMI. J. Runhaar, D. P. Beavers, G. D. Miller et al. Osteoarthritis Cartilage. 2019. https://doi.org/10.1016/j.joca.2019.04.009.

2. The role of inflammation, oxidative stress, angiogenesis, and apoptosis in the pathophysiology of endometriosis: Basic science and new insights based on gene expression. M. Samimi, M. H. Pourhanifeh, A. Mehdizadehkashi et al. J Cell Physiol. 2019. https://doi.org/10.1002/jcp.28666.

3. Benefits and risks of nonsteroidal anti-inflammatory drugs: methodologic limitations lead to clinical uncertainties. M. A. Rane, J. G. Foster, Wood S. K. et al. Ther Innov Regul Sci. 2018. https://doi. org/10.1177/2168479018794159.

4. Walker C., Biasucci L. M. Cardiovascular safety of non-steroidal anti-inflammatory drugs revisited. Postgrad Med. 2018. V. 130 (1). P. 55-71. https://doi.org/10.1080/00325481.

5. Перспективы использования фитопрепаратов в современной фармакологии. Т. В. Самбукова, Б. В. Овчинников, В. П. Ганапольский и др. Обзоры по клинической фармакологии и лекарственной терапии. 2017. Т. 15. С. 56-63. https://doi.org/10.17816/RCF15256-63.

6. Mandal G., Chatterjee C., Chatterjee M. Evaluation of anti-inflammatory activity of methanolic extract of leaves of Bougainvillea spectabilis in experimental animal models. Pharmacognosy Res. 2015. № 7 (1). P. 18-22. https://doi.org/10.4103/0974-8490.147194.

7. Murthuraman and Singh. Attenuating effect of Acorus calamus extract in chronic constriction injury induced neuropathic pain in rats: an evidence of anti-oxidative, anti-inflammatory, neuroprotective and calcium inhibitory effects. BMC Complementary and Alternative Medicine. 2011. № 11. P. 24.

8. Кароматов И. Д. Аир болотный и его применение в медицине. Молодой ученый. 2015. № 7. С. 296-302.

9. Доклінічні дослідження лікарських засобів (метод. рекоменд.); за ред. чл.-кор. НАМН України О. В. Стефанова. Київ : ВД «Авіцена», 2001. 528 с. 
10. European convention for the protection of vertebrate animals used for experimental and other scientific purposes. Council of Europe, Strasbourg, 1986. 53 p.

11. Клиническая лабораторная диагностика: методы исследования. И. А. Зупанец, С. В. Мисюрева, В. В. Прописнова и др.; под ред. И. А. Зупанца. 3-е изд., перераб. и доп. Харьков : Изд-во НФаУ: Золотые страницы, 2005. 200 с.

12. Реброва О. Ю. Статистический анализ медицинских данных. Применение пакета прикладных программ STATISTICA. 3-е изд. Москва : МедиаСфера, 2006. 312 с.

13. Bronner C., Landry $Y$. Kinetics of inhibitory effect of flavonoids on histamine secretion from mast cells. Agents and Actions. 1985. № 16. Р. 147-151.

14. Пожилова Е. В. Влияние антигипоксантов на развитие каррагенин-индуцированного воспаления. Российский медико-биологический вестник имени академика И. П. Павлова. 2014. № 4. С. 61-67.

\section{Л. А. Коранг, Л. В. Деримедвідь}

\section{Антиексудативні властивості рідкого спиртово-водного екстракту листя аїру звичайного (Acorus calamus L.)}

Мета дослідження - вивчення антиексудативних властивостей рідкого спиртово-водного екстракту листя аїру звичайного (Acorus calamus L.) (РСВЕЛА).

РСВЕЛА був отриманий на кафедрі ботаніки НФаУ під керівництвом професора Т. М. Гонтової.

Протизапальні властивості РСВЕЛА досліджені на білих безпородних щурах на моделях карагенінового та гістамінових набряків. Досліджуваний РСВЕЛА (0,5 мл / кг) і препарати порівняння, а саме: диклофенак натрію (у дозі 8 мг / кг), кверцетин (у дозі 11 мг / кг) і лоратадин (у дозі 1 мг / кг), на моделі карагенінового та гістаміновими набряків застосовували в лікувально-профілактичному режимі: внутрішньошлунково одноразово щодня протягом 5 діб до моделювання запалення й за 1 год до ін'єкції флогогену (карагеніну або гістаміну відповідно). Розвиток набряку спостерігали в динаміці за показником об'єму лапи, який визначали за допомогою цифрового плетизмометра. Через 24 год після введення флогогену в тварин визначали кількість лейкоцитів і шOE.

Встановлено, що на моделі карагенінового та гістамінового набряку РСВЕЛА чинить протинабрякову дію. Антиексудативна активність РСВЕЛА склала 68,9 \% (р < 0,05) на 120 хв запалення та $79,5 \%(p<0,05)$ на 180 хв у разі карагенінового набряку.

На моделі гістамінового набряку антиексудативна дія РСВЕЛА склала 50, 8; 27,7 і 50,0 \% відповідно на 30, 60 і 90 хв набряку. За виразністю антиексудативної дії, ступенем зниження ШОЕ та показника лейкоцитозу РСВЕЛА не поступається всім трьом препаратам порівняння: диклофенаку натрію, кверцетину і лоратадину.

Таким чином, встановлено, що РСВЕЛА має антиексудативну дію, що є обгрунтуванням подальших досліджень з перспективою створення на його основі нових ефективних фітопрепаратів для профілактики та фармакокорекції запальних процесів.

Ключові слова: Acorus calamus L., карагеніновий набряк, гістаміновий набряк, рідкий спиртововодний екстракт листя аїру звичайного, антиексудативна активність

\section{Л. А. Коранг, Л. В. Деримедвидь}

\section{Антиэкссудативные свойства жидкого спиртово-водного экстракта листьев аира обыкновенного (Acorus calamus L.)}

Цель исследования - изучение антиэкссудативных свойств жидкого спиртово-водного экстракта листьев аира обыкновенного (Acorus calamus L.) (РСВЕЛА).

РСВЕЛА был получен на кафедре ботаники НФаУ под руководством проф. Т. М. Гонтового.

Антиэкссудативные свойства РСВЕЛА исследованы на белых беспородных крысах на модели каррагенинового и гистаминового отеков. Исследуемый РСВЕЛА (0,5 мл / кг) и препараты сравнения: диклофенак натрия (в дозе 8 мг / кг), кверцетин (в дозе 11 мг / кг) и лоратадин (в дозе 1 мг / кг) на модели каррагенинового и гистаминового отеков применяли в лечебно-профилактическом режиме: внутрижелудочно однократно ежедневно в течение 5 сут до моделирования воспаления и за 1 ч до инъекции флогогена (каррагенина или гистамина соответственно). За развитием отека наблюдали в динамике по показателю объема лапы, который определяли с помощью цифрового плетизмометра. Через 24 ч после введения флогогена у животных определяли количество лейкоцитов и СОЭ.

Установлено, что на модели каррагенинового и гистаминового отеков РСВЕЛА оказывает антиэкссудативное действие. Антиэкссудативная активность РСВЕЛА составила 68,9 \% $(p<0,05)$ на 120 мин воспаления и 79,5 \% ( $<$ 0,05) на 180 мин при каррагениновом отеке.

На модели гистаминового отека антиэкссудативное действие РСВЕЛА составило 50,8; 27,7 и 50,0 \% соответственно на 30, 60 и 90 мин отека. По выраженности антиэкссудативного действия, степени снижения СОЭ и лейкоцитоза РСВЕЛА не уступает всем трем препаратам сравнения: диклофенаку натрия, кверцетину и лоратадину.

Таким образом, установлено, что РСВЕЛА оказывает антиэкссудативное действие, что обосновы- 
вает дальнейшие исследования с перспективой создания на его основе новых эффективных фитопрепаратов для профилактики и фармакокорекции воспалительных процессов.

Ключевые слова: Acorus calamus L., каррагениновый отек, гистаминовый отек, жидкий спиртово-водный экстракт листьев аира обыкновенного, антиэкссудативная активность

\section{A. Korang, L. V. Derymedvid \\ Anti-exudative properties of liquid alcohol-water extract of sweet flag leaves (Acorus Calamus L.)}

The purpose of the study is to investigate the anti-exudative properties of a liquid alcohol-water extract of Sweet Flag leaves (Acorus Calamus L.) (RSVELA) .

RSVELA was obtained at the Department of Botany of NPhAU by post-graduate student M. S. Yaremenko supervised by Prof. T. M. Gontova.

The anti-exudative properties of RSVEL were investigated on outbred white rats and performed on the models of carrageenan and histamine induced edema/inflammation.

The development of carrageenan induced inflammation/edema was observed at 30, 60, 90, 120, 180, $240 \mathrm{~min}$ and after $24 \mathrm{~h}$. The histamine induced model was observed at 30,60 and $90 \mathrm{~min}$. A digital plethysmometer Panlab (Spain) was used to measure the volume of animal's paws $\left(\mathrm{cm}^{3}\right)$.

RSVELA (test dose of $0,5 \mathrm{ml} / \mathrm{kg}$ ) was diluted with water and administered intragastrically. The following drugs were used as comparisons: Diclofenac sodium (8 $\mathrm{mg} / \mathrm{kg})$ - classic non-steroidal anti-inflammatory drug; quercetin $(11 \mathrm{mg} / \mathrm{kg}$ ) - phytopreparation with the predominant antileukotriene mechanism of action in the model of histamine induced edema; loratadine $(1 \mathrm{mg} / \mathrm{kg})$ - antihistamine preparation with antiexudative effect.

The investigational product and comparison drugs were used with the following regimen: intragastrically once daily for 5 days before simulation of inflammation, the last time $1 \mathrm{~h}$ before phlogogen injection (carrageenin and histamine, respectively).

$24 \mathrm{~h}$ after simulating carrageenin and histamine inflammation in animals, clinical blood tests were performed. Leukocyte count and ESR were determined using standard methods.

The anti-exudative properties of RSVELA on the model of carrageenan edema at the level of 10,0-79,5\% at which RSVELA were not inferior in comparison to well-studied preparations: diclofenac sodium (28,7$80,1 \%)$ and quercetin $(4,6-80,1 \%)$ throughout the study period. The anti-exudative activities of RSVELA were observed (maximum inflammation) 68,9\% $(p<0,05)$ at $120 \mathrm{~min}$ and 79,5\% $(p<0,05)$ at $180 \mathrm{~min}$.

After administering RSVELA in the model of carrageenan edema, the level of leukocytes decreased by 1,3 times ( $p \leqslant 0,01$ as compared with untreated animals), and the ESR decreased by 1,35 times. When diclofenac sodium was used, leukocyte levels decreased by 1,4-times, and ESR decreased by 1,5-times compared with untreated animals $(p \leqslant 0,01)$. And when quercetin was used, leukocyte level decreased by 1,2 -times $(p \leqslant 0,05)$ and the ESR - 1,2 times. Such changes indicate decrease an intensity of the inflammatory process when using RSVELA and diclofenac sodium, and the presence of anti-inflammatory action in quercetin.

In the histamine edema model, the anti-inflammatory effect of RSVELA was 50,8; 27,7 and 50,0 \%, respectively after 30,60 and $90 \mathrm{~min}$ of simulating edema/inflammation. Also, after administration of RSVELA there was 1,2-times decrease ( $p \leqslant 0,01$ as compared with untreated animals) of leukocyte levels and ESR. The degree of the anti-exudative activity of RSVELA is not inferior to all three comparison drugs: diclofenac sodium, quercetin and loratadine, which suggests the ability of the studied extract to have an inhibitory effect on mediators of the early phase of the inflammatory process, mainly biogenic amines.

Conclusion: it was found that the RSVELA has an anti-exudative properties, which were found on the models of carrageenan and histamine induced edema. The data obtained could be used as the basis for further preclinical studies of RSVELA with the aim of creating new effective phytotherapeutic medicine for prevention and pharmacotherapy of inflammatory processes.

Key words: Acorus calamus L., carrageenan edema, histamine edema, liquid alcohol-water extract of Sweet Flag leaves, anti-exudative activity

Прийнята до друку: 4 вересня 2019 р.

Надійшла: 17 липня 2019 p.

Контактна особа: Деримедвідь Л. В., Національний фармацевтичний університет, буд. 53, вул. Пушкінська, м. Харків, 61000. Електронна пошта: derimedved67@gmail.com 